\title{
Esporulação de Erythricium salmonicolor e de Seu Anamorfo Necator decretus, Agente Causal da Rubelose dos Citros no Brasil
}

\author{
Sylvia R. G. Moraes ${ }^{1}$, Gleiber Q. Furtado ${ }^{1}$, Érika A. G. Scaloppi², Modesto Barreto ${ }^{3}$ \& Nelson S.M. Júnior. ${ }^{1}$ \\ ${ }^{1}$ Departamento de Entomologia, Fitopatologia e Zoologia Agrícola, ESALQ, Universidade de São Paulo, Cx. Postal 09, \\ CEP 13418-900, Piracicaba, SP, e-mail: nmassola@esalq.usp.br; ${ }^{2}$ Laboratório de Fitopatologia, Instituto Biológico, \\ Cx. Postal 70, CEP 13001-970, Campinas, SP; ${ }^{3}$ Departamento de Fitossanidade, Faculdade de Ciências Agrárias e \\ Veterinárias, Universidade Estadual Paulista, CEP 14884-900, Jaboticabal, SP.
}

(Aceito para publicação em 18/12/2006)

Autor para correspondência: Nelson S. Massola Júnior

\begin{abstract}
Sporulation of both Erythricium salmonicolor and its anamorphic stage Necator decretus, causal agent of citrus pink disease in Brazil

The sporulation of Erythricium salmonicolor and its anamorph Necator decretus, causal agent of pink disease is reported for the first time on citrus in Brazil.
\end{abstract}

A rubelose dos citros tem causado danos significativos à citricultura paulista nos últimos anos. A doença concentra-se nos galhos e ramos, sendo mais severa em árvores vigorosas e em pomares adensados. Os sintomas iniciais consistem em lesões com desprendimento da casca e exsudação de goma. Posteriormente, observam-se cordões miceliais e crescimento micelial róseo sobre os ramos afetados (Figura 1A). Internamente, nesses ramos, observa-se descoloração dos tecidos. Quando essas lesões atingem a base dos galhos, pode ocorrer a morte de toda a copa da planta. Mesmo com o avanço dessa doença nos últimos anos, até então nenhuma estrutura reprodutiva do patógeno havia sido relatada em citros no Brasil (Feichtenberger et al., Manual de Fitopatologia, Vol. 2, p.239. 2005). Ramos de laranjeira Valência e Pêra-Rio afetados pela doença, com crescimento micelial róseo na superfície, foram coletados no município de Matão e Brotas, estado de São Paulo, em julho e outubro de 2004, respectivamente. Esses materiais foram preparados para visualização em microscopia de luz e microscopia eletrônica de varredura, com o objetivo de detectar a presença da esporulação do patógeno. Para microscopia de luz, foram realizadas raspagens superficiais, com auxílio de agulha histológica e, posteriormente, preparação de lâminas em lactoglicerol. Para a visualização ao microscópio eletrônico de varredura, as amostras foram preparadas conforme Kitajima \& Leite (Curso introdutório de microscopia eletrônica de varredura. 1999). Para o procedimento convencional, as amostras foram fixadas em solução de Karnovsky modificada (2,5\% glutaraldeído e $2,5 \%$ de formaldeído em tampão caccodilato de sódio 0,05M - pH 7,2 e $\mathrm{CaCl}_{2}$ 0,001M), seguindo-se imersão em solução de tetróxido de ósmio e desidratação em série de acetona. Posteriormente, foram secas ao ponto crítico em $\mathrm{CO}_{2}$ e metalizadas com vapor de ouro. A observação foi realizada ao microscópio eletrônico de varredura Zeiss modelo DMS 940A. Para a criofratura, as amostras foram fixadas em solução de Karnovsky modificada, infiltradas com crioprotetor, imersas em nitrogênio líquido e cortadas com auxílio de um escalpelo. Em seguida foram processadas como descrito anteriormente. As imagens obtidas por meio de ambas microscopias comprovaram a ocorrência de esporulação do agente causal da rubelose dos citros, tanto da fase teleomórfica quanto da anamórfica. A fase teleomórfica [Erythricium salmonicolor (Berk. \& Broome) Burds.] é caracterizada pela produção de basídios com basidiósporos (Figuras 1B, C) e a fase anamórfica (Necator decretus Massee) por conídios formados em esporodóquios (Figuras 1C, D). Os conídios encontrados são unicelulares, esféricos a ovais, medindo 8,4-13,4 x 5,6-9,8 $\mu \mathrm{m}$, com média de 11,0-8,1 $\mu \mathrm{m}$. A confirmação da identidade do fungo foi realizada com base em literatura específica (Mordue \& Gibson, CMI Descriptions of Pathogenic Fungi and Bacteria 511, 1976). A ocorrência de esporulação nas fases basidial e conidial de E. salmonicolor em citros poderão amparar estudos epidemiológicos para auxiliar na compreensão da crescente ocorrência da rubelose no Brasil.

Agradecimentos: Ao FUNDECITRUS pelo apoio financeiro.

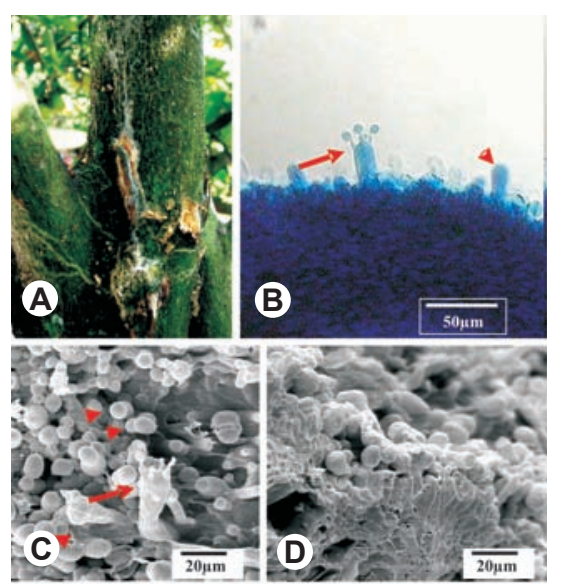

FIG. 1 - A. sintomas de rubelose em planta de Pêra-Rio; nota-se os cordões miceliais; B. basídio com basidiósporos (seta) e basídio jovem (pontas de seta) de E. salmonicolor, vistos ao microscópio de luz; C. coexistência das fases teleomórfica (seta) e anamórfica (pontas de seta), vista em microscopia eletrônica de varredura; D. esporodóquio de $N$. decretus fraturado em nitrogênio líquido, exibindo conídios. 